
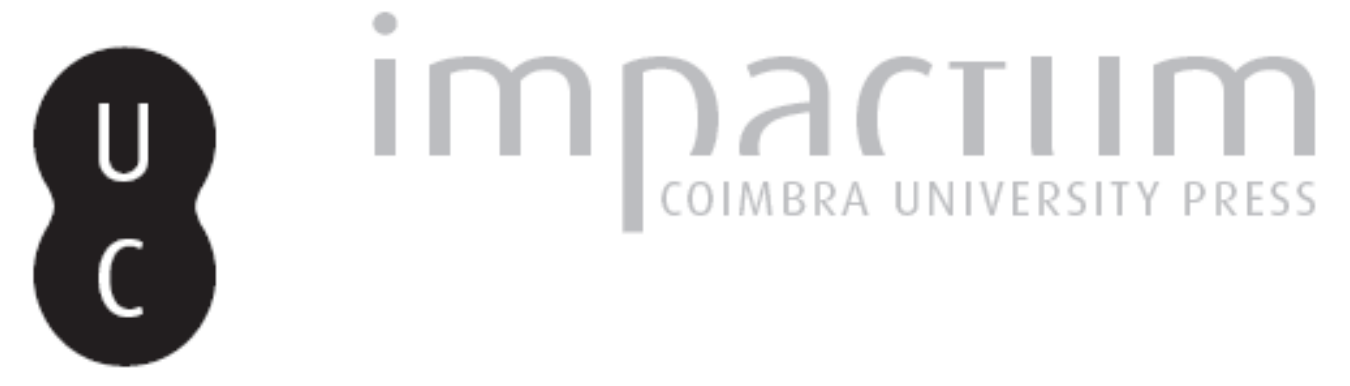

\title{
As práticas de caridade na diocese de Mariana: estímulos devocionais, interditos e protestos anónimos no século XVIII
}

Autor(es): $\quad$ Santos, Patrícia Ferreira dos

Publicado por: Centro de História da Sociedade e da Cultura

URL persistente:

URI:http://hdl.handle.net/10316.2/39482

DOI:

DOI:http://dx.doi.org/10.14195/1645-2259_11_8

Accessed : $\quad$ 26-Apr-2023 10:25:45

A navegação consulta e descarregamento dos títulos inseridos nas Bibliotecas Digitais UC Digitalis, UC Pombalina e UC Impactum, pressupõem a aceitação plena e sem reservas dos Termos e Condições de Uso destas Bibliotecas Digitais, disponíveis em https://digitalis.uc.pt/pt-pt/termos.

Conforme exposto nos referidos Termos e Condições de Uso, o descarregamento de títulos de acesso restrito requer uma licença válida de autorização devendo o utilizador aceder ao(s) documento(s) a partir de um endereço de IP da instituição detentora da supramencionada licença.

Ao utilizador é apenas permitido o descarregamento para uso pessoal, pelo que o emprego do(s) título(s) descarregado(s) para outro fim, designadamente comercial, carece de autorização do respetivo autor ou editor da obra.

Na medida em que todas as obras da UC Digitalis se encontram protegidas pelo Código do Direito de Autor e Direitos Conexos e demais legislação aplicável, toda a cópia, parcial ou total, deste documento, nos casos em que é legalmente admitida, deverá conter ou fazer-se acompanhar por este aviso.

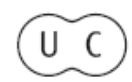




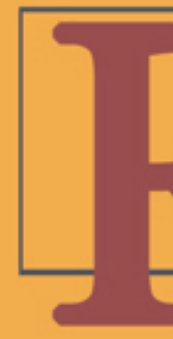

\section{evista de História} da Sociedade e da Cultura

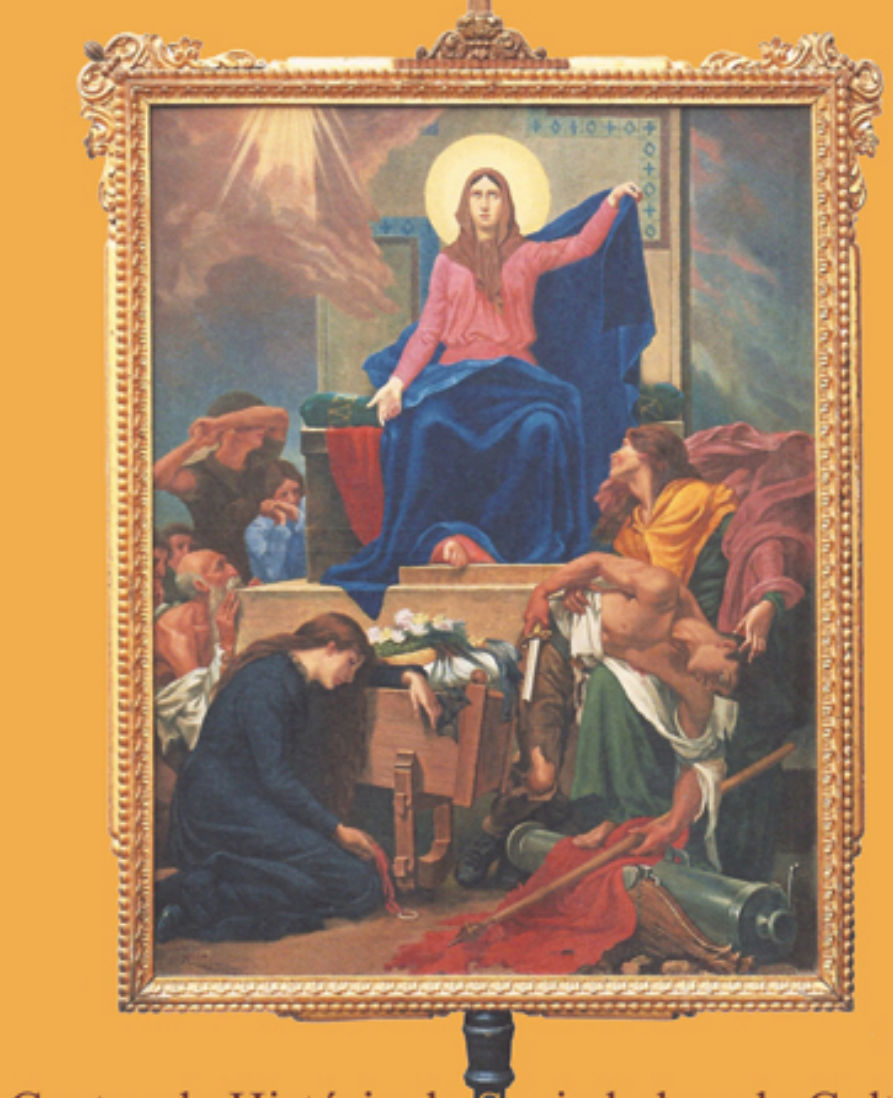

Centro de História da Sociedade e da Cultura Universidade de Coimbra 


\title{
As práticas de caridade na diocese de Mariana: estímulos devocionais, interditos e protestos anónimos no século XVIII*
}

\author{
Patrícia Ferreira dos Santos \\ Universidade de São Paulo \\ Mestre em História Social \\ psantos@usp.br
}

Texto recebido em/ Text submitted on: 12/10/2010

Texto aprovado em/ Text approved on: 31/10/2011

\section{Resumo/Abstract:}

Neste artigo analisamos algumas acções da hierarquia eclesiástica e secular na diocese de Mariana no sentido de condicionar a acção dos esmoleres e ermitães e incentivar a caridade institucional. As cartas e atas de visitas pastorais que ali circularam, no século XVIII, estabeleciam penas de prisões e confiscos de cofres aos pedintes sem licenças. Sugerem que o Estado e a Igreja procuraram, a um só tempo, impedir a evasão das contribuições, e reprimir as heterodoxias praticadas por benzedores e curandeiros. Os agentes coloniais apregoavam um discurso em prol da solidariedade pelas vias institucionais. Por outro lado, murmurações e protestos anónimos circularam em diversas freguesias do bispado de Mariana.

This article aims to review some of the actions of the secular and the ecclesiastical hierarchy in the diocese of Mariana in order to constrain the activities of beggars and hermits and encourage charitable institutions. The letters and minutes of pastoral visits that circulated, established penalties of imprisonment and confiscation of safes to beggars without permits suggest that State and the Church sought, at the same time prevent the evasion of contributions, and suppress the heterodoxies blesser and practiced by healers. The colonial agents preached a discourse in order to solidarity for the institutional channels. On the other hand, there are, anonymous grumbling and protests, which circulated in several parishes in the diocese of Mariana.

Palavras chave/Keywords:

Esmolas; Ermitães; Visitas pastorais; Hierarquia eclesiástica; Padroado real.

Alms; Hermits; Pastoral visits; Church hierarchy; Royal patronage.

* Agradeço à Fundação de Amparo à Pesquisa do Estado de São Paulo o apoio à presente pesquisa de doutoramento sobre o exercício da autoridade e da justiça episcopal no século XVIII. 


\section{Os pedintes e as instituições de assistência em Portugal}

As figuras dos pedintes de esmolas eram tão comuns nos Setecentos, que inspiraram medidas de condicionamento e repressão da parte da Igreja e da Coroa, assim como sátiras anônimas. Estas, tornaram célebres as desconfianças que suscitavam aqueles que viviam a pedir esmolas. O anônimo do século XVIII observava que este poderia ser um rentável meio de vida. Justificava sua crítica tenaz a enumerar exemplos: "Que direi de infinitos que, a título de pobres, se fazem ricos? Abrem chagas nas pernas e nos braços com cáusticos e ervas; mostram suas dores com brados" e assim, "muitos mil juntam esses piratas".

Com riqueza de exemplos, o Anônimo relata situações e estratagemas que revelavam os usos indevidos das esmolas: "Sê-lo-ão mil esmolas, pelo menos, que cada dia vemos pedir, com capa de piedade e misericórdia, para pobres, para missas e irmandades, as quais vão arder na mesa do jogo ou da gula. Um mulato conheci, que tinha uma opa branca - que comprou na roupa velha por dois tostões -, com a qual, com uma bacia e duas voltas que dava por quatro ruas, todos os dias, pedindo para as missas de Nossa Senhora, juntava o que lhe bastava para passar alegremente a vida. Também este furtava com unhas bentas." ${ }^{2}$

Estas sátiras suscitam a indagação sobre quem seriam os esmoleres e esmoleiros, e em quais circunstâncias e condições pediam esmolas. O dicionário do padre Raphael Bluteau, de 1712, apresenta verbetes relacionados ao ato de pedir esmolas. Convém distinguir, deste modo, as características que diferenciavam os esmoleiros dos que pediam sem as devidas licenças eclesiásticas, e eram, por isso, considerados vadios. Bluteau esclarece que o esmoler era o "caritativo com os pobres"; ou aquele que "por ofício distribuía as esmolas." O esmoleiro era "aquele religioso que num convento de mendicantes recolhe as esmolas." Por

1 Anônimo do Século XVIII. Arte de Furtar: espelho de enganos, teatro de verdades, mostrador de horas minguadas, gazua geral destes reinos de Portugal oferecida a El-Rei Nosso Senhor Dom João IV para que a emende. Apresentação de João Ubaldo Ribeiro. Porto Alegre: L\&PM, 2005. (L\&PM Pocket, 430), pp. 194-195. «Dos que furtam com unhas bentas.»

2 Anônimo do Século XVIII. Op. Cit., pp. 194-195. «Dos que furtam com unhas bentas.» 
seu turno, a hierarquia eclesiástica reivindicava uma autoridade legítima, em seu território de jurisdição, de arrecadar as esmolas para fins específicos, junto aos fiéis; de apontar os destinos lícitos para as suas contribuições e, por conseguinte, o poder de condicionar a ação dos pedidores, concedendo ou negando licenças, e punindo os que burlassem a ordem estabelecida. Assim, dispunha de oficiais encarregados de arrecadar as esmolas e contribuições específicas junto aos fiéis em suas paróquias. ${ }^{3}$

Para o caso analisado neste texto, releva o ofício do mamposteiro da Bula da Santa Cruzada - que foi alvo de algumas contestações anónimas na diocese de Mariana. O verbete organizado por Bluteau define o mamposteiro como o "homem posto por mão de alguém para algum negócio." O verbete mamposteiro deriva do latim, e significa "estender a mão para receber as esmolas." Bluteau esclarece que havia diversos tipos de mamposteiro, sendo que o da Bula da Santa Cruzada "arrecada as esmolas da Bula da Sagrada Cruzada, e há mamposteiros mores e menores."4

$\mathrm{O}$ cotejo destes verbetes e sátiras a respeito dos esmoleiros e oficiais eclesiásticos chama a atenção, por conseguinte, para a presença e atuação de agentes diversos no campo religioso. Concebido por Pierre Bourdieu, o conceito de campo religioso enfoca o convívio sócio-religioso de atores diferenciados pela posição que ocupam na estrutura social. Deste modo, a sua ação social deve ser analisada de forma a considerar os interesses diversos pelos quais eram movidos: os sacerdotes, como emissores da mensagem religiosa; os leigos, como alvos. ${ }^{5}$

3 BLUTEAU, Raphael. Vocabulário portuguez, e latino, áulico, anatômico, architectonico, bellico, botânico (...). Coimbra: Collegio das Artes da Companhia de Jesus, 1712. Verbetes: esmoleiro, esmoler e mamposteiro, respectivamente pp. 251 e 277-78.

4 BLUTEAU, Raphael. Vocabulário portuguez, e latino, áulico, anatômico, architectonico, bellico, botânico (...). Coimbra: Collegio das Artes da Companhia de Jesus, 1712. Verbetes: esmoleiro, esmoler e mamposteiro, respectivamente pp. 251 e 277-78.

5 Em sua elaboração conceitual do campo religioso, por outro lado, Pierre Bourdieu observou que mostram-se diversos, os interesses religiosos das classes dominantes e os das classes dominadas - estas, tenderiam a uma demanda de salvação, enquanto as primeiras, à demanda de legitimação da ordem. BOURDIEU, Pierre. "Gênese e estrutura do campo religioso". In: A Economia das Trocas Simbólicas. Vários tradutores. $2^{\mathrm{a}}$ reimpressão da 6 a edição de 2005. São Paulo: Perspectiva, 2009, p. 27ss (Estudos; 20) 
Por outro lado, este aspecto torna relevante observar, conforme os estudos de Michel de Certeau, que os leigos, muitas vezes, não se limitariam ou acomodariam necessariamente ao papel de receptores da mensagem religiosa. A análise das fontes eclesiásticas mostra que a contestavam e burlavam com frequência, a desenvolver e lançar mão de estratégias variadas para, nos interstícios das próprias engrenagens institucionais, conseguir realizar as suas práticas e fazeres cotidianos. ${ }^{6}$

A seguir procederemos, com estes referenciais teóricos a orientar o estudo das fontes eclesiásticas, a uma caracterização do campo religoso na capitania de Minas Gerais. no que se refere às esmolas, nota-se a presença de agentes da hierarquia eclesiástica que deveriam zelar pela arrecadação das contribuições, conforme as orientações da Igreja. Por outro lado, era comum que pessoas devotas solicitassem permissão para pedir esmolas por devoção ou promessa. Todavia, como veremos, uma vez atuando nas circunscrições eclesiásticas de uma diocese, estes devotos deveriam sujeitar-se às regras e condicionamentos quanto ao período e os locais determinados pela cúria para efetuar seus pedidos de esmolas. Tendo em vista o predomínio que reivindicava do campo religioso, a hierarquia eclesiástica empreenderia uma luta na capitania, prefigurada no trabalho religioso, que tendia a ações de destruição e exclusão aos seus concorrentes - os profetas, feiticeiros e heréticos, entre outros agentes da heterodoxia. ${ }^{7}$

Em seu trabalho religioso na capitania, a hierarquia eclesiástica procurava discernir o lícito do ilícito, e assim, persuadir os diocesanos da sua autoridade em apontar e punir aqueles desvios. Assim, a mensagem religiosa era propagada pelas paróquias e capelanias da diocese. Com frequência, apontava os batuques, as artes divinatórias e curatórias e o culto ancestral como transgressões à ordem e à fé cristã. Via de regra, aqueles que

${ }^{6}$ Para Michel de Certeau, afora a investigação das instituições, proposto por Pierre Bourdieu, a pesquisa deste universo institucional deve considerar os consumidores dos produtos institucionais. Defende Certeau que a importância de buscar enxergar esta resistência significa não tomar os outros por idiotas. Nos interstícios do trabalho de coerção institucional encontram-se microliberdades, microrresistências, e uma liberdade gazeteira das práticas. Por entre as determinações das instituições dão-se, ainda, as trocas sociais, as invenções técnicas e as resistências morais. CERTEAU, Michel de. A Invenção do quotidiano, vol 1. As artes de fazer. Trad. Ephraim Ferreira Alves. $16^{\mathrm{a}}$ ed. Petrópolis: Vozes, 2009, pp. 38-39.

7 BOURDIEU, Pierre. Op. Cit., p. 27 ss. 
participassem ou consentissem naquelas práticas eram admoestados em sermões. Se fossem descobertos durante as visitas pastorais, prescreviam-se as punições previstas nas Constituições do bispado. Consideradas transgressões às leis da Igreja e do Estado, tais práticas também poderiam ser vistas como nocivas ao sossego público pelos agentes da coroa. Estes, porém, na visão do brasilianista Donald Ramos, diferiam da Igreja quanto ao rigor aplicado na repressão. De modo que, muito embora este autor considere tais manifestações como uma "voz popular", defende que a sua recorrência sugeriria um certo equilíbrio entre o rigor e a tolerância por parte das autoridades. ${ }^{8}$

De igual forma, a hierarquia eclesiástica tendia a apontar, como veremos, os destinos mais lícitos às contribuições dos fiéis, estabelecendo um controle sobre os canais de assistência nas comunidades. Eram várias, àquela altura, as instituições cujas atividades estavam ligadas a este fim. As Misericórdias, por exemplo, estavam sob a autoridade da coroa. De acordo com Isabel dos Guimarães Sá, após a publicação dos decretos do Concílio de Trento (1545-1563), "a posição das Misericórdias saiu consolidada a nível político." Àquela ocasião, "os monarcas portugueses conseguiram alcançar um estatuto jurídico para as Misericórdias.” Elas passaram a ser confrarias sob proteção régia, ou seja, instituições que, embora de índole religiosa, estavam sob a jurisdição do rei. Deste modo, mantinham os seus objetivos religiosos sem ser uma instituição da Igreja. Para a autora, este caráter misto, religioso no espírito, mas leigo e régio no foro judicial, permitiu às Misericórdias "sobreviver até aos dias de hoje, ao contrário da maior parte das ordens religiosas e das outras confrarias (eclesiásticas, isto é, sob a autoridade episcopal), que sofreram rudes golpes com as revoluções liberais". ${ }^{9}$

Em Portugal, como mostra esta mesma autora, outras práticas de caridade e assistência eram importantes. Entre estas, menciona o costume de se ajudar jovens órfãs a se casar, uma vez que não possuíam dote. Também no bispado

8 RAMOS, Donald. “A 'voz popular' e a cultura popular no Brasil do século XVIII”. In: SILVA, M. B. N. Cultura Portuguesa na Terra de Santa Cruz. Lisboa: Estampa,1995, p. 138.

9 SÁ, Isabel dos Guimarães. In: SÁ, Isabel dos Guimarães; LOPES, Maria Antônia. História Breve das Misericórdias. Coimbra: Imprensa da Universidade de Coimbra, p. 2008, Parte I - De 1489 a 1750, pp. 35-36. 
de Mariana verificam-se as presenças, nas câmaras municipais, dos juízes de órfãos e dos ausentes, bem como a responsabilidade com as despesas de pagamento das amas ou criadeiras, que deveriam cuidar das crianças expostas, ou abandonadas..$^{10}$ Isso ocorria porque, conforme aponta Renato Venâncio, "as leis portuguesas mencionavam que os hospitais, em primeiro lugar, deveriam arcar com o socorro a meninos e meninas abandonados. $\mathrm{Na}$ falta de hospitais, o Senado da Câmara deveria dar início ao serviço de assistência." 11

Observa-se, deste modo, uma adaptação aos territórios de conquista, das práticas tradicionais e institucionalizadas de assistência em Portugal. Nota-se, na diocese de Mariana, uma permanente tendência de controle, pelo Estado e pela Igreja, para que as práticas de caridade fossem exercidas no âmbito de instituições específicas; as quais, se não alocadas sob a jurisdição do rei ou do bispo diocesano, que ao menos se impusesse a necessidade de uma chancela oficial, aplicada a confrarias e associações e esmoleiros. Em especial na zona mineradora, bastante vigiada pela coroa no século XVIII, como veremos.

\section{As instituições eclesiásticas, a assistência e a presença dos pedintes na capitania de Minas Gerais}

A intensa correspondência das autoridades da capitania de Minas Gerais com o conselho ultramarino de Lisboa revela a tentativa da coroa de controlar a sociedade em formação em Minas Gerais no século XVIII. Por meio das centenas de cartas e consultas, a coroa lusa e os seus ministros registavam e cobravam das autoridades locais providências que atendessem aos imperativos da atividade mineradora e fiscalista na região. A capitania foi povoada sob os auspícios do direito de padroado, e a tarefa do controle

${ }^{10}$ SÁ, Isabel dos Guimarães. Op. Cit., p. 38. VENÂNCIO, Renato Pinto. "Estrutura do Senado da Câmara.” In: TERMO de Mariana: História e documentação. Ouro Preto: Imprensa Universitária da Universidade Federal de Ouro Preto, 1998, pp. 139-140.

${ }^{11}$ VENÂNCIO, Renato Pinto. Famílias abandonadas: assistência à criança de camadas populares no Rio de Janeiro e em Salvador - Séculos XVIII e XIX. Campinas, São Paulo: Papirus, 1999, pp. 24-25. 
social deveria ser partilhada pelos agentes eclesiásticos e seculares. Em trabalho pioneiro no tratamento desta questão, Caio César Boschi ressaltou a natureza das relações entre estas instituições, em seu estudo acerca da presença das irmandades nas relações Estado-Igreja em Minas Gerais no século XVIII. A coroa, segundo aponta, "não estabeleceu, em linhas precisas, uma política para a região." Mas fez vigorar uma legislação dispersa, da qual se destacava a lei que proibiu a entrada de religiosos seculares, sob a alegação de que estes eram os responsáveis pelo extravio do ouro e por insuflar a população ao não-pagamento de impostos. Para Caio Boschi, diante disso, a vida religiosa da nova capitania passou a ser fortemente influenciada por associações leigas. ${ }^{12}$

Caracterizando o campo religioso da capitania, o estudo de Caio Boschi ressalta dois aspectos de especial relevância: primeiro, a estreita interpenetração entre a Igreja e o Estado, nas formas de marcar presença na vida religiosa e social na capitania de Minas Gerais; e segundo, a forte influência das normas tridentinas nas formas de organização eclesiástica. ${ }^{13}$

Outrossim, os estudos de Fernando Torres-Londoño trouxeram contribuições importantíssimas sobre a organização eclesiástica colonial, a chamar a atenção para a importância central da rede paroquial na organização da vida religiosa e social na colônia. A estruturação da paróquia, ressaltou o autor, teve as suas características mais importantes definidas pelo Concílio de Trento. Muito embora, muito antes, em Portugal, observa-se que a paróquia assumia as funções de controle social, com um exercício de vigilância da vida moral e religiosa dos fiéis regulamentado pelas constituições sinodais. Torres-Londoño observou que na paróquia, à época colonial, consagrava-se

${ }^{12}$ BOSCHI,Caio César. Os leigos e o poder. Irmandades Leigas e politica colonizadora em Minas Gerais. São Paulo: Ática, 1986, p. 1 - Introdução. (Ensaios, 116).

${ }^{13}$ BOSCHI,Caio César. Os leigos e o poder. Op. Cit., pp. 45-47. Sobre este aspecto das relações entre a Igreja e o Estado, seguimos de perto as elaborações interpretativas de: PAIVA, José Pedro de M. "El estado en la Iglesia y la Iglesia en el Estado: contaminaciones, dependencias y disidencia entre la monarquia y la Iglesia del reino de Portugal (1495-1640)". Traducción de Ignasi Fernández Terricabras. Manuscrits, n. 25, 2007. Separata. Barcelona: Universidad Autónoma de Barcelona. 
uma "estrutura de poder centralizada no pároco que, dentre os vários objetivos, visava à normatização das crenças e da conduta dos fiéis." 14

Ao mesmo tempo em que é evidente esta importância das paróquias como núcleo de consolidação da presença eclesiástica, Caio Boschi chama a atenção para o fato de que "quem se debruça sobre a religiosidade colonial não pode ter como parâmetro as normas e os padrões do catecismo doutrinal, ditado pela teologia e pelo direito canônico." Para o autor, o que se vê na colônia portuguesa na América é predominantemente um catolicismo popular marcado pela precariedade da evangelização e pela hipertrofia das constelações devocional e protetora. ${ }^{15}$

Juntamente com o clássico livro de Julita Scarano, os estudos de Caio Boschi abriram trilhas para que investigações posteriores corroborassem com exemplos da proliferação das linhas devocionais, por meio de associações leigas com oragos diversos. Adalgisa Arantes Campos demonstrou o incremento em número dos sodalícios em honra ao Arcanjo São Miguel e as Almas naquele contexto, marcado por uma oratória sacra que ressaltava a existência do Purgatório e os fins últimos do Homem - Morte, Juízo, Inferno e Paraíso. Por sua vez, Marcos Magalhães de Aguiar analisou as formas de controle estabelecidas pela coroa para estabelecer a fiscalização das irmandades, e as suas contas, mostrando que estas foram motivo de conflitos entre os ouvidores e os visitadores delegados. ${ }^{16}$

Com efeito, dom frei Manuel da Cruz relatou, em 1757, à Sagrada Congregação do Concílio de Trento, os seus cuidados no sentido de tomar as contas das irmandades fundadas por autoridade episcopal no bispado de Mariana. Esclarecia que "no tempo das visitas, exigem os Visitadores rigorosa conta disto e verificam com atenção se os Legados, com que se

14 TORRES-LONDOÑO, Fernando. (Org.) Paróquia e comunidade no Brasil: perspectiva histórica. São Paulo: Paulus, 1997, p. 12-Introdução; idem. A Outra Família: Concubinato, Igreja e escândalo na Colônia. São Paulo: Loyola, 1999.

${ }^{15}$ BOSCHI,Caio César. Os leigos e o poder. Op. Cit., p. 59.

${ }^{16}$ SCARANO, Julita. Devoção e Escravidão: a irmandade de Nossa Senhora do Rosário dos Pretos no Distrito Diamantino. $2^{\mathrm{a}}$ ed. São Paulo: Nacional, 1978. (Brasiliana). CAMPOS, Adalgisa Arantes. A terceira devoção do Setecentos mineiro: o culto a São Miguel e almas. São Paulo, Doutorado. FFLCH-USP, 1994, 3-4; 13; 52; 89; 118; 167-168; 262-263; 311-317; AGUIAR, M. M. Vila Rica dos confrades: a sociabilidade confrarial entre negros e mulatos no século XVIII. São Paulo: FFLCH-USP, 1993, Mestrado, pp. 263-264. 
comprometeram as Igrejas, foram executados. ${ }^{17}$ Mas o ouvidor da comarca de Vila Rica compilava vários papéis e relatos de pessoas que andaram pela região desde os primeiros movimentos de sua ocupação. Provara que muitos sodalícios haviam sido fundados antes da chegada do bispo, e que as suas contas não poderiam ser apresentadas aos visitadores. Entre relatos sobre os rendimentos do bispado, o clero, irmandades e paróquias, o Códice Costa Matoso contém centenas de documentos que mostram que a capitania de Minas Gerais se organizava, nos primórdios dos descobrimentos auríferos, em meio a uma violência extrema, crises de fome e de abastecimento. ${ }^{18}$

Como ressaltou Caio Boschi, o Estado, no princípio, não estabeleceu, em linhas precisas, uma política para a região. Uma legislação dispersa, de cunho acentuadamente absolutista, destacava a lei que proibiu a entrada de religiosos seculares, sob a alegação de que estes eram os responsáveis pelo extravio do ouro e por insuflar a população ao não-pagamento de impostos. Todavia, observa-se uma presença marcante de numeroso clero a edificar majestosos templos, os quais são, ainda hoje marcos da civilização que se criou em função da exploração aurífera. O autor defende que parte da explicação destas circunstâncias encontra-se no estudo das irmandades constituídas por leigos. De modo que parecia importante ao Estado e à Igreja, em uma forma de convergência de seus objetivos de doutrinação e apaziguamanto social, deter o avanço da violência e do extravio de riquezas. Diante disso, defende o autor, "toda a vida religiosa da nova capitania passou a ser acionada por associações leigas." 19

Na segunda metade do século XVIII, as pressões metropolitanas no sentido de reprimir o contrabando e os extravios de riquezas e aumentar a eficácia dos mecanismos de administração da justiça e aplicação das

17 "Relatório do episcopado de Mariana para a Sagrada Congregação do Concílio Tridentino", § 5. , p. 83. In: CADERNOS Históricos do Arquivo Eclesiástico da Arquidiocese de Mariana: os Relatórios Decenais enviados à Santa Sé - Visitas Ad Limina, Vol. 3. Organização e notas do Monsenhor Flávio C. Rodrigues. Mariana: Ed. Dom Viçoso, 2005, pp. 81-82.

${ }^{18}$ CÓDICE Costa Matoso. Coleção das notícias dos primeiros descobrimentos das Minas na América que fez o Doutor Caetano da Costa Matoso, sendo ouvidor geral das do Ouro Preto, de que tomou posse em Fevereiro de 1749 \& vários papéis. Belo Horizonte: Fundação João Pinheiro/CEHC, 1999. (Mineiriana. Série Obras de Referência).

${ }^{19}$ BOSCHI, Caio César, Op. Cit., pp. 2-3; p. 59. 
punições foram intensificadas. Isto se observou de forma mais incisiva, com a organização das Juntas de Justiça em todos os lugares onde houvessem ouvidores. Estas circunstâncias devem ser situadas no conetxto das Reformas Pombalinas, em curso em Portugal, com a ascensão do ministro de dom José I, Sebastião José de Carvalho e Melo, o futuro Marquês de Pombal. Elas iniciavam, em meados do século XVIII, um processo de mudanças jurídico-administrativas e económicas em Portugal. Isto se deu de modo especial com as providências por ele capitaneadas para a reconstrução de Lisboa após o terremoto, e a expulsão dos jesuítas. Por seu turno, a organização eclesiástica receberia o impacto das reformas pombalinas. ${ }^{20}$

De igual forma, como apontou Maria Antónia Lopes, as Misericórdias sofreriam maiores intervenções na época pombalina do que nos tempos anteriores, demarcando maior controle, comportamento que também se verifica nos dois reinados posteriores. ${ }^{21}$

Como não poderia deixar de ser, também o bispo dom frei Manuel da Cruz sentiria, em seus provimentos, as diferenças entre as políticas estabelecidas no reinado de dom José I e na de seu pai, Dom João V. Em 1757, informava à Sagrada Congregação do Concílio Tridentino, por meio de Relatório Decenal de sua Visita Ad Limina à Santa Sé, que o bispado que assumira em 1748 possuía "quarenta e três igrejas paroquiais naiores, com Reitores colados, três ainda amovíveis e duzentas e oitenta e nove igrejas menores, filiadas às primeiras." ${ }^{22}$

O trabalho religioso levado a cabo pelo bispo, porém, tendia a uma intensificação na fundação paróquias encomendadas, vez que os provimentos de igrejas coladas pela coroa demoravam anos. Malgrado o fato de os núcleos novos ou em desenvolvimento necessitarem da presença de sacerdotes,

${ }^{20}$ PAIVA, José Pedro. “A Igreja e o poder.” In: AZEVEDO, C. M. (dir.) História Religiosa de Portugal. Lisboa: Círculo de Leitores, 2000, vol. 2 - Humanismos e Reformas, pp. 173-74. MAXWELL, Kenneth. O Marquês de Pombal: paradoxo do Iluminismo. $2^{\mathrm{a}}$ edição. Rio de Janeiro: Paz e Terra, 1996, p. 168.

${ }^{21}$ LOPES, Maria Antónia. História Breve das Misericórdias. Coimbra: Imprensa da Universidade de Coimbra, p. 2008, Parte II - De 1750 a 2000. Nos finais da Monarquia Absoluta, pp. 65-66.

22 "Relatório do episcopado de Mariana para a Sagrada Congregação do Concílio Tridentino”, § 1. , p. 81. In: CADERNOS Históricos do Arquivo Eclesiástico da Arquidiocese de Mariana: os Relatórios Decenais enviados à Santa Sé - Visitas Ad Limina, V. 3. Organização e notas do Monsenhor Flávio C. Rodrigues. Mariana: Ed. Dom Viçoso, 2005, pp. 81-82. 
nem sempre o rei dom José I confirmava os feitos do bispo, ou autorizava as divisões. Estudos apontam que, muitas vezes, a designação dos colados não obedecia a desígnios pastorais, e os resíduos - as diferenças entre receita e despesa - dos dízimos arrecadados pela coroa não eram inteiramente destinados às melhorias da rede paroquial. ${ }^{23}$

O problema era que nas paróquias encomendadas, os fregueses deveriam arcar com o complemento material à igreja e à sustentação do pároco, que não dispunha como os colados, ou perpétuos, da côngrua anual paga pela Fazenda Real. Os bispos faziam estes provimentos temporários, estabelecendo as paróquias chamadas encomendadas. Seus párocos eram amovíveis e não selecionados através de concursos. Deles se fazia a única exigência de idoneidade moral. Deveriam ser sustentados pela comunidade. Esta situação tornou usual a cobrança das conhecenças; eram bilhetes de confissão, pagos por ocasião das desobrigas. Como todos tinham de se confessar na quaresma, os párocos, a quem pertencia a contribuição, faziam o recenseamento de seus paroquianos, casa por casa, e davam bilhetes como talões de recibos, por cabeça dos maiores, que comungavam, e a metade, por cabeça dos menores, que não comungavam. Da mesma forma, cobrava-se também os chamados pés-de-altar: emolumentos pagos pelos batismos, casamentos e funerais. Os párocos alegavam que as cobranças reuniam muito pouco para seu sustento. Por outro lado, o fardo se revelava pesado frente a pobreza dos fregueses. ${ }^{24}$

Neste universo de pobreza e proliferação das devoções populares, era compreensível que a hierarquia eclesiástica temesse a atuação de benzedores e feiticeiros. Como ressaltou Fernando Torres-Londoño, benzedores eram

${ }^{23}$ FONSECA, C. D. Des terres aux villes de l'or: pouvoir et territoires urbaisn dans Minas Geraus aux XVIII siécle. Paris: Fundação Calouste Gulbenkian, 2002, pp. 86; 96-97.

${ }^{24}$ VASCONCELLOS, Diogo de. História do bispado de Mariana. Belo Horizonte: Edições Apollo, 1935. (Biblioteca Mineira de Cultura), p. 19; TORRES-LONDOÑO, Fernando. (Org.) Paróquia e Comunidade. Op. Cit., pp. 57-60; CÓDICE Costa Matoso. Coleção das notícias dos primeiros descobrimentos das Minas na América que fez o Doutor Caetano da Costa Matoso, sendo ouvidor geral das do Ouro Preto, de que tomou posse em Fevereiro de 1749 \& vários papéis. Belo Horizonte: Fundação João Pinheiro/CEHC, 1999. (Mineiriana. Série Obras de Referência). Vol. 2. Verbetes "Pároco", "Vigário Colado" e "Vigário Encomendado". 
personagens incómodos à cúria episcopal. A Reforma Católica conseguia, "por cooptação ou marginalidade controlar as devoções populares". Assim, desclassificou, através do discurso acerca da ignorância religiosa, rezadores, benzedeiras e demais lideranças religiosas leigas, que desde a colônia vinham disputando o monopólio do sagrado com os párocos. ${ }^{25}$

Como ressaltou Fernando Torres-Londoño, "ficou evidente a importância da paróquia para a administração da igreja desde o período colonial. Através dela, a instituição eclesiástica, com sua hierarquia e seu corpus normativo, se fez presente." 26

\section{O Estado e a Igreja em Minas Gerais: a propósito de algumas formas de condicionamentos aos pedintes}

Em seu Relatório Decenal de 1757, à Sagrada Congregação do Concílio de Trento, o bispo de Mariana ressaltava, que não havia na diocese nenhum mosteiro de regulares, cujo demasiado relaxamento havia censurado, "mesmo os de Portugal que transitam impunemente por estas plagas bastante extensas. Mas eu me apliquei em contê-los nos claustros de suas Ordens e nos limites das Dioceses: remédio mais eficaz, contudo, ao afastamento deles trouxeram as Ordenanças do Rei ameaçador. Assim ficou totalmente livre a diocese de semelhantes pessoas vadias; permaneceram somente aqueles Sacerdotes estrangeiros que servem ao ministério dos Sacramentos."27

Acerca do exercício da caridade na capitania de Minas Gerais, dom frei Manuel da Cruz informava:

Desde os primórdios de sua criação até hoje, a Igreja de Mariana toma vulto, mas não se faz conhecida por nenhum Montepio, nenhum estabelecimento de Misericórdia Pública. Em determinada vila, a pouca

${ }^{25}$ TORRES-LONDOÑO, Fernando. (Org.) Paróquia e comunidade no Brasil: perspectiva histórica. São Paulo: Paulus, 1997, pp. 6-11- Introdução.

${ }^{26}$ TORRES-LONDOÑO, Fernando. (Org.) Paróquia e comunidade no Brasil, Op. Cit., p. 6 - Introdução.

27 "Relatório do episcopado de Mariana para a Sagrada Congregação do Concílio Tridentino", op. Cit., § $4^{\circ}$, p. 83. 
distância daqui, um único hospital, construído com parcos recursos no começo da criação do bispado, pode assistir pequeno número de enfermos $(\ldots)^{28}$

Os títulos das Constituições Primeiras do Arcebispado da Bahia que tratam da regulamentação das esmolas denotam o temor de que as esmolas se tornassem, para alguns, um meio de vida. A hierarquia eclesiástica não ignorava o fato de existirem muitos esmoleres a pedir pelas circunscrições eclesiásticas da sua jurisdição. Assim, observa-se que, por meio do discurso pastoral propagado nas paróquias e capelanias, os interdições e condicionamentos seriam impostos aos esmoleiros e pedidores.

Assim verifica-se, na capitania de Minas Gerais, àquela altura, uma convergência entre as acções dos dignitários de cargos seculares e eclesiásticos para efectuar o controlo das licenças para os esmoleres e interditar os pedintes. Em 31 de Dezembro de 1754, o secretário de Estado Diogo de Mendonça Côrte-Real emitiu um aviso, em Lisboa, no qual determinava a Estêvão de Menezes, o Marquês de Penalva, que ordenasse aos ouvidores e ministros do bispado de Mariana que não consentissem que os eremitas permanecessem pedindo esmolas, a não ser com a licença do bispo daquela diocese, Dom Frei Manuel da Cruz. A coroa legitimava, deste modo, a proibição às esmolas, anunciada pela cúria. ${ }^{29}$

Naquele contexto, a hierarquia eclesiástica assumia um papel de fiscalização e condicionamento do espaço público. Sendo assim, os oficiais da cúria episcopal deveriam analisar cuidadosamente a devoção do eremita e os casos nos quais poderiam conceder licenças, obrigatórias para que pudessem arrecadar quaisquer fundos. Era, ainda, condição sine qua non que, caso obtivessem as licenças, eles só pudessem pedir dentro dos prazos e lugares determinados pela câmara episcopal. Ainda, orientava-se que, quando concedidas, as licenças para esmoleres e ermitães com caixinhas

28 "Relatório do episcopado de Mariana para a Sagrada Congregação do Concílio Tridentino", op. Cit., $\S 5^{\circ}$, p. 84.

${ }^{29}$ Arquivo Histórico Ultramarino, AHU/MG/Lisboa, 31/12/1754, Cx. 66, doc. 72. Aviso de Diogo de Mendonça Corte-Real, determinando ao Marquês de Penalva, Estêvão de Menezes, que ordene aos ouvidores e ministros do Bispado de Mariana que não consintam que os eremitas estejam pedindo esmolas, somente com licença do Bispo Dom Frei Manuel da Cruz, da referida diocese. 
deveriam ser sempre curtas e condicionadas a períodos de tempo e lugares determinados. Os pedidos de esmolas deveriam acontecer apenas nos adros de algumas igrejas, mediante certidão jurada diante dos párocos e esclarecimentos do pedinte, se pedia esmolas por devoção ou promessa que houvesse feito. ${ }^{30}$

Quando o pedinte não contava com a devida sanção, na forma de licença in scriptas, poderia ser preso e ter todo o seu montante arrecadado confiscado. Estes procedimentos eram regulamentados pelas Constituições da Bahia, que justificavam-no pelos enganos e falsidades possibilitados pela prática de pedir esmolas. ${ }^{31}$

Desta forma, o controlo das esmolas e os esmoleres constituíram matéria de consensos entre eclesiásticos, agentes seculares e conselheiros ultramarinos, no século XVIII. Consensos que se reverteriam em taxativos interditos, impostos aos pedintes na Capitania de Minas, sob pena de prisões, perseguições e confisco de cofres. Nota-se que dom Frei Manuel da Cruz, primeiro bispo de Mariana, adotava a justificativa das Constituições, no sentido de crer que o trato com os esmoleres pedia semelhante cautela, pelo risco de suas licenças contribuírem para a atenção de interesses próprios, transformando a devoção num negócio. ${ }^{32}$ Ao pároco caberia a interdição aos ermitães com caixinhas e o poder de detê-los, segundo documento do Arquivo Eclesiástico da Arquidiocese de Mariana:

${ }^{30}$ Copiador de algumas cartas particulares do Excelentíssimo e Reverendíssimo. Dom Frei Manuel da Cruz (1739-1762), fl. 106v. Transcrição, Organização e notas de Aldo Luiz Leoni. Ouro Preto: Universidade Federal de Ouro Preto, 2003. Brasília: Editora do Senado, 2009. Copiador de algumas cartas particulares de Dom Frei Manuel da Cruz. Organização de Monsenhor Flávio Carneiro Rodrigues e Maria José Ferro. Mariana: Dom Viçoso, 2008., fls.183v.

${ }^{31}$ CONSTITUIÇÕES Primeiras do Arcebispado da Bahia, Feitas e Ordenadas pelo Ilustríssimo e Reverendíssimo Dom Sebastião Monteiro da Vide. São Paulo: Tipografia 2 de Dezembro, 1853. Livro IV. Título LXIII: Das esmolas, questores e pedidores. Que não haja questores e pedidores de esmolas, e como se procederá contra eles, parágrafos 876-878; Título LXIV: Que ninguém peça esmolas em licença, e como se concederá, Parágrafo 879-882.

${ }^{32}$ Copiador de algumas cartas particulares do Excelentíssimo e Reverendíssimo. Dom Frei Manuel da Cruz (1739-1762). Transcrição, Organização e notas de Aldo Luiz Leoni. Ouro Preto: Universidade Federal de Ouro Preto, 2003. Brasília: Editora do Senado, 2009. Copiador de algumas cartas particulares de Dom Frei Manuel da Cruz. Organização de Mons. Flávio Carneiro Rodrigues e Maria José Ferro. Mariana: Dom Viçoso, 2008, fls.183v. 
Achando o reverendo pároco ou capelães das capelas que algum ermitão anda com hábito e caixinha pedindo esmolas sem a licença de sua Excelência Reverendíssima ou de seus visitadores, lhes poderá sequestrar as esmolas, caixinha e hábito que tem e terão com o dito ermitão, procedendo ao vigário da vara da comarca, informando-se juntamente se o dito tem mais esmolas guardadas em alguma parte, de que também darão conta ao vigário da vara. ${ }^{33}$

Outras justificativas seriam apresentadas para aquela severidade: o livre exercício dos pedintes abria uma perigosa margem a heterodoxias. ${ }^{34}$

Em estudo clássico sobre a pobreza na capitania conhecida pela riqueza aurífera e a opulência, a historiadora Laura de Mello e Souza demonstrou como as autoridades coloniais, civis e eclesiásticas, se locupletavam na repressão e nos condicionamentos às pessoas vadias e ociosas. Naquele contexto, as festas e as cerimônias públicas eram um instrumento de representação hierárquica, que simulava a ilusão de congraçamento social. Para a autora, o reforço da hierarquia escondia o temor das contestações à tênue e recente ordem estabelecida nas Minas. Segundo Laura de Mello e Souza, a festa, igualando as diferenças, ao mesmo tempo as acentuava, conferindo espaço ao gentio da terra e ao mulato. Compunha um fenômeno de inversão ideológica ao constituir um dos únicos relatos que referiam à opulência de uma sociedade na qual havia extrema pobreza, e que atravessara profundas e recentes crises de fome. ${ }^{35}$

Da mesma forma que as festas e cerimônias públicas, a difusão da mensagem religiosa era outro recurso de persuasão junto às gentes incultas da capitania de Minas Gerais. Atendia, desta forma, ao interesse oficial de controlo social das práticas de assistência à pobreza no bispado, por meio do estímulo às devoções católicas e a veneração dos seus modelos.

${ }^{33}$ Visita do Doutor Visitador Manuel Ribeiro Taborda por Dom Frei Manuel da Cruz delegado à freguesia de Nossa Senhora da Boa Viagem de Curral Del Rei, em 20/08/1753. AEAM, Livro de Disposições Pastorais número 3, prateleira W, fl. 14.

${ }^{34}$ PAIVA, José Pedro. "El Estado en La Iglesia y La Iglesia en el Estado: contaminaciones, dependencias y disidencia entre la monarquía y la Iglesia del reino de Portugal (1495-1640)." Manuscripts, 25, 2007, p. 51-52.

${ }^{35}$ SOUZA, Laura de M. e. Desclassificados do ouro: a pobreza mineira no século XVIII. Rio de Janeiro: Graal, 2004.pp. 44-52. 


\section{A caridade na mensagem religiosa: prática e devoção}

Todos eram convocados à participação na construção do Reino de Deus. Este trabalho religioso levaria de freguesia em freguesia do bispado de Mariana um discurso incisivo contra os falsos pedintes. Nesse sentido, os pregadores, visitadores e o próprio bispo seriam enfáticos na apresentação de modelos de caridade cristã para a imitação dos fiéis. Assim, ao mesmo tempo em que se estabeleceram condicionamentos aos esmoleres, conforme as constituições do bispado, ermitães e pedintes, a hierarquia eclesiástica realizava um trabalho de exortação, em prol da solidariedade a ser desenvolvida no âmbito institucional. Nos sermões e cartas pastorais, assim como as atas das visitas às freguesias, o discurso pastoral apregoava a caridade. ${ }^{36}$

A promoção da caridade implicava também em uma regulamentação rigorosa das esmolas, as quais deveriam expressar a fé cristã. Praticar a caridade através de piedosas esmolas era parte da missão de todo fiel católico, pois esta era apontada como a virtude mãe. Assim, a prática da solidariedade, nas freguesias, deveria ser colocada a serviço da Igreja. O discurso pastoral apontava os destinos legítimos para as contribuições espontâneas.

Em visita de 1759 à freguesia de Nossa Senhora da Conceição da Boa Viagem de Curral Del Rei, o Doutor José dos Santos, padre visitador, seguiu esta linha de orientação. Inicialmente, exortava a população ao exercício da caridade, seguindo os divinos exemplos de Jesus, Maria e José. Delegado por Dom Frei Manuel da Cruz, o visitador explicava aos fiéis que deveriam fazê-lo em imitação ao modelo implantado na Sé Catedral do Bispado. Relatava que lá havia uma numerosa irmandade, que possuía como o seu principal exercício "a Santa Caridade. Em seu ofício, os irmãos pediam esmolas tanto de ouro como de mantimentos que se destinariam à distribuição entre os pobres, miseráveis, presos, órfãos, viúvas." ${ }^{\text {37 }}$

${ }^{36}$ Visita do doutor José dos Santos à freguesia de Nossa Senhora da Boa Viagem de Curral del Rei, 13/11/1759. Aeam, Seção de Livros Paroquiais, Prateleira W, Livro 3, Disposições Pastorais (1727-1853), fl. 32.

${ }^{37}$ Visita do doutor José dos Santos à freguesia de Nossa Senhora da Boa Viagem de Curral del Rei, 13/11/1759. Aeam, Seção de Livros Paroquiais, Prateleira W, Livro 3, Disposições Pastorais (1727-1853), fl. 32. 
Residindo na única capitania da América Portuguesa na qual se permitia circulação de ouro em pó, os fiéis da freguesia deveriam pedir esmolas nos arraiais vizinhos, seguindo o exemplo oficialmente apontado. Os donativos que arrecadassem deveriam ser distribuídos aos mais carentes. Estas acções ficariam aos cuidados do pároco, auxiliado por pessoas "pias e tementes a Deus". Das contribuições arrecadadas, uma quantia deveria ser reservada. Tratava-se do pré-dote, que se destinava, no caso específico daquela freguesia, em 1759, à compra das imagens dos Três Santíssimos Corações. Esta devoção cada vez mais crescia e se fortalecia, no bispado de Mariana, eleita a representação mais exemplar da perfeita caridade. As imagens dos Três Sagrados Corações haviam sido solenemente entronizadas na catedral em 1755; foi quando houve também muito estrépito, devido às discordâncias de uma parte do cabido. ${ }^{38}$

A hierarquia eclesiástica comandada por dom frei Manuel da Cruz, por sua vez, incentivava a difusão deste culto. As imagens dos Sagrados Corações de Jesus, Maria e José, símbolos da caridade, deveriam ser entronizadas também nas matrizes e capelas das freguesias do bispado, para que os fiéis afervorassem a sua devoção e progredissem naquela santa virtude. Assim como a devoção Mariana, a caridade era apontada como sinal de predestinação dos escolhidos. O culto a Maria Santíssima deveria ser afervorado. A carta pastoral de Dom Frei António de Guadalupe, que ilustrava esta temática, foi novamente publicada e lida aos fiéis. ${ }^{39}$

Percorrendo todo o bispado, o visitador levava a orientação episcopal respeitante às esmolas. Elas eram definitivamente associadas ao dever de todo fiel para com a caridade cristã. Em visita pastoral à freguesia encomendada de Nossa Senhora da Conceição das Catas Altas, o Doutor

${ }^{38}$ Sobre este e outros episódios de conflitos envolvendo a hierarquia eclesiástica de Mariana, vide: TRINDADE, R. O. (Côn.) A Arquidiocese de Mariana: subsídios para sua História, $1^{a}$ edição. Liceu Coração de Jesus, São Paulo, 1929, 2v; $2^{a}$ edição. Belo Horizonte: Imprensa Oficial, 1953, 2 volumes. SANTOS, Patrícia Ferreira. Poder e palavra: discursos, contendas e direito de padroado em Mariana (1748-1764). 2010 (Estudos Históricos, 83), pp. 207-220 - A mitra e o cabido; pp. 154-168 - A vivência religiosa sensível: a graça e a ira divina).

${ }^{39}$ Visita do doutor José dos Santos à freguesia de Nossa Senhora da Boa Viagem de Curral del Rei, 13/11/1759. Aeam, Seção de Livros Paroquiais, Prateleira W, Livro 3, Disposições Pastorais (1727-1853), fls.33-34. 
José dos Santos orientou o vigário encomendado José Bernardo da Costa, para que, com a maior brevidade possível, fizesse pôr nas paredes, as cruzes da Via Sacra. Deveria admoestar os fregueses para freqüentá-la e meditar sobre os sofrimentos; assim lucrariam as indulgências pela devoção. O padre José dos Santos agia conforme orientação de Dom Manuel da Cruz. Como mais uma prova de sua confiança neste sacerdote, que tivera uma longeva atuação como vigário geral do bispado de Mariana entre 1750 e 1756, o bispo o nomearia visitador geral do bispado de Mariana em carta pastoral de $1760 .^{40}$

As visitas pastorais arrecadavam, àquela altura, fundos oriundos das condenações e multas cometidas aos réprobos e os pecadores públicos - assim, representavam um elo com o tribunal eclesiástico. Conforme as Constituições, o montante arrecadado nas visitas era dividido em três partes: a primeira pertence ao meirinho-geral, a segunda às despesas da justiça, e a terceira à Sé catedral. As visitas pastorais também se afiguravam como ocasiões para apresentar, aos fiéis, os destinos justos e lícitos para as suas contribuições. ${ }^{41}$

Também o ordinário diocesano promovia este trabalho de persuasão, com o recurso das cartas pastorais, de ampla circulação, em todo o bispado, e de leitura obrigatória nos dias de grande concurso de pessoas. O Recolhimento de Nossa Senhora da Conceição do Monte Alegre das Macaúbas foi apontado pelo primeiro bispo de Mariana como um destino muito agradável a Deus para receber as esmolas dos fiéis. O bispo elogiara também à Sagrada Congregação do Concílio de Trento. Em relatório, apontava-o como um modelo edificante de virtude feminina. Dom frei Manuel da Cruz o havia visitado pessoalmente e relatou aos fiéis as suas impressões: "com edificação grande do meu espírito, achei que as recolhidas vivem com suma perfeição em todos os actos de comunidade". Explicou aos fiéis como era a vida delas: frequentavam "com activo fervor o coro,

${ }^{40}$ Idem.

${ }^{41}$ Copiador de algumas cartas particulares do Excelentíssimo e Reverendíssimo. Dom Frei Manuel da Cruz (1739-1762). Transcrição, Organização e notas de Aldo Luiz Leoni. Ouro Preto: Universidade Federal de Ouro Preto, 2003. Brasília: Editora do Senado, 2009. Copiador de algumas cartas particulares de Dom Frei Manuel da Cruz. Organização de Mons. Flávio Carneiro Rodrigues e Maria José Ferro. Mariana: Dom Viçoso, 2008, fls. $112 \mathrm{v} ; 114-115 \mathrm{v} ; 173 \mathrm{v} ; 209 \mathrm{v}-210$. 
em que além do ofício divino que rezam primorosamente, meditam também os mistérios do Rosário de Nossa Santíssima Mãe e Senhora Maria Santíssima, rezando outrossim muitas preces e devotas orações". No entanto, asseverava, "com grande mágoa minha achei que muitas pessoas por não saberem da virtude com que as mesmas recolhidas vivem, se esquecem de as socorrer com suas esmolas de que muito carecem para a comodidade da vida". Assim, recomendara ao reverendo pároco e capelães que exortassem a seus fregueses e aplicados para que se compadecessem das freiras em suas esmolas. Assim, eatariam a contemplar um "propugnáculo fortíssimo contra o Inferno e um poderoso escudo desta capitania de Minas, e posto destes respeitos, exorto também às pessoas que fazem testamentos na sua freguesia lhes queiram deixar seus legados e esmolas". Como contrapartida, o bispo garantia aos benfeitores: "receberão grandes retribuições assim nesta vida como na Eterna". ${ }^{42}$

Outro destino indicado à generosidade dos testadores e dos demais fiéis foi o sustento do Seminário fundado pelo primeiro bispo de Mariana em 20 de Dezembro de 1750. Dom Frei Manuel da Cruz o construíra logo que assumiu a diocese, em atenção às directrizes tridentinas e à orientação da bula de sua nomeação. Na época, o bispo sonhara poder entregá-lo à direcção do padre jesuíta Gabriel Malagrida. Era seu grande amigo pessoal, o fervoroso padre, e velho companheiro de pregações nos sertões do nordeste. Porém, durante o ministério pombalino encontraria um trágico e absurdo fim. Em 1761, foi perseguido em Lisboa, e preso e condenado pela Inquisição, sob a influência do Conde de Oeiras, Sebastião José de Carvalho e Melo. ${ }^{43}$

Na região mineradora, a dificuldade dos moradores de garantir estudos aos seus filhos foi o mote para a consecução da provisão régia de Setembro de 1748, que ordenava a criação do seminário. Afirmava o bispo que "todo este dinheiro procedeu de esmolas que os fiéis deram para o seminário e juntamente de doações que lhe fizeram e de legados pios". ${ }^{44}$ Os registos

${ }^{42}$ Pastoral de sua Excelência Reverendíssima, D. Manuel da Cruz, julho de 1761. AEAM, Secção de Livros Paroquiais, prateleira W, Livro 3, Disposições Pastorais (1727-1853), fl. 33-34.

${ }^{43}$ AZEVEDO, João Lúcio de. O marquês de Pombal e a sua época. Lisboa: Alfarrábio, 2009, pp. 121-122.

${ }^{44}$ TRINDADE, R. O. (Côn.) Op. Cit.., vol.1, p. 378-379. 
evidenciam que sobrevivia à custa das esmolas e benfeitorias de alguns fiéis. À época da fundação da instituição de ensino, augurava o bispo a Dom João V que "para se fazer um dormitório novo pelo tempo adiante não hão-de faltar esmolas, pois todo este povo está com muito gosto, e alvoroço, neste novo seminário". ${ }^{45}$

Com efeito, os fiéis do bispado corresponderam à comprovada vocação do primeiro bispo para com o ensino e a formação sacerdotal. Em sua provisão de fundação do seminário, Dom Frei Manuel da Cruz esclarecia a sua invocação - Nossa Senhora da Boa Morte - e a localização, nas casas compradas ao Cónego Francisco Ribeiro da Silva por doze mil cruzados. Gratificado, dom frei Manuel da Cruz esclarecia "que se lhe satisfizeram do produto das esmolas dos fiéis cristãos". Os rendimentos do seminário, declarados pelo próprio bispo, envolviam as chácaras com casas que rendiam juntas $452 \$ 363$. Havia, ainda, um pecúlio no valor de 6: $845 \$ 250$, que estavam a juros "a seis e quatro por cento e importam em cada hum ano $427 \$ 828$ ", rendimento ao qual se somava a quantia de $880 \$ 191$ e ainda "vinte mil cruzados para se comprar uma ou duas fazendas de gado no sertão", para o sustento dos padres mestres e para a continuidade das obras, "com o dinheiro acima e com as esmolas que se forem adquirindo." ${ }^{46}$

José de Torres Quintanilha, benfeitor abastado, havia doado uma chácara à Rua da Olaria, que confrontava com a estrada pública que conduzia à freguesia de Guarapiranga, e pelos fundos, com o mesmo antigo Córrego da Intendência. Doou também um escravo para o serviço do seminário, sob condição de poder se transferir para lá e viver gratuitamente até completar

${ }^{45}$ Copiador de algumas cartas particulares do Excelentíssimo e Reverendíssimo. Dom Frei Manuel da Cruz (1739-1762). Transcrição, Organização e notas de Aldo Luiz Leoni. Ouro Preto: Universidade Federal de Ouro Preto, 2003. Brasília: Editora do Senado, 2009. Copiador de algumas cartas particulares de Dom Frei Manuel da Cruz. Organização de Mons. Flávio Carneiro Rodrigues e Maria José Ferro. Mariana: Dom Viçoso, 2008., fls. 112v; $114-115 \mathrm{v} ; 173 \mathrm{v} ; 209 \mathrm{v}-210$.

${ }^{46}$ Copiador de algumas cartas particulares do Excelentíssimo e Reverendíssimo. Dom Frei Manuel da Cruz (1739-1762). Transcrição, Organização e notas de Aldo Luiz Leoni. Ouro Preto: Universidade Federal de Ouro Preto, 2003. Brasília: Editora do Senado, 2009. Copiador de algumas cartas particulares de Dom Frei Manuel da Cruz. Organização de Mons. Flávio Carneiro Rodrigues e Maria José Ferro. Mariana: Dom Viçoso, 2008., fls. 112v; 114-115v; 173v; 209v-210. 
seus estudos ou falecer. Deveriam, ainda, ser rezadas, à capela, três missas por semana em sua intenção, perpetuamente. ${ }^{47}$

\section{Concessões, abusos e contestações no contexto da capitania do ouro}

$\mathrm{Na}$ documentação do Juízo Eclesiástico do bispado de Mariana, cujo acervo reúne as provisões concedidas pelo foro gracioso, bem como as demandas do foro contencioso, podem também ser localizadas muitas petições nas quais religiosos de outros bispados solicitam licenças e contribuições daquela diocese, considerada rica. Este foi o caso deste processo, encontrado no Arquivo Eclesiástico da Arquidiocese de Mariana, no qual o Frei João de Monserrate Cotia se dirigia ao cabido em sede vacante, como "seu irmão mais afetuoso e certo venerador", com uma petição, fazendo súplica de esmolas. Explicava que escrevia "para lhes fazer evidente o estado de pobreza e opressão a que está reduzido este convento (que estava) em tal empenho que só por meio de uma infatigável diligência ajudada da piedade dos fiéis poderá respirar da opressão em que se vê." ${ }^{48}$

Outrossim, na região de Minas Gerais também se buscou arrecadar esmolas para a construção de um Seminário na diocese de Coimbra. Através de uma carta em 1753, Dom Frei Manuel da Cruz solicitava a devida permissão, pelo Conselho Ultramarino, "havendo no bispado de Coimbra uma universidade pública e muitos estudos públicos, está o bispo daquela diocese fundando actualmente um seminário, e além de the ter unido alguns benefícios, mandou com licença de Vossa Majestade pedir esmolas nesse bispado". ${ }^{49}$

Na documentação do foro contencioso do juízo eclesiástico, há, por outro lado, denúncias e testemunhos de petições ilícitas de esmolas, bem como furtos e usos indevidos..$^{50} \mathrm{O}$ cotejo destes casos de concessões e demandas

${ }^{47}$ TRINDADE, R. O. (Côn.) Arquidiocese de Mariana: subsidios para sua História, $2^{\text {a }}$ Ed. Belo Horizonte: Imprensa Oficial, 1953, vol.1, p. 379.

${ }^{48}$ AEAM. Foro Gracioso, Epistolário dos Bispos, 1619. São Paulo, 20 de jul. de 1783.

49 TRINDADE, R. O. (Côn.) Op. Cit., vol.1, p. 378-379.

${ }^{50}$ Arquivo Eclesiástico da Arquidiocese de Mariana - AEAM. Juízo Eclesiástico, processos/ números: 2768, fl. 220-221; 2756 - cobranças por esmolas estipuladas em testamento, fl. 134v; 2786 - exemplo do sacerdote que arrecada esmolas para utilizar na 
fazem notar que, controlando a formas de arrecadações das esmolas no bispado de Mariana, os representantes da Igreja indicavam aos fiéis os destinos merecedores das contribuições, e, por outro lado, procuravam conter os abusos e usos oportunistas.

As esmolas poderiam, ainda, originar novos tributos. Isto era algo bem pior do que a tentativa de arrecadar fundos em situações especiais. As duas circunstâncias se fizeram notar em Minas Gerais. À ocasião da notícia do terramoto de Lisboa, a partir de 1755, houve uma comoção geral no bispado. A cúria episcopal realizou persistentes apelos à população, para que fizessem contribuições e donativos. A calamidade gerou um imposto, cobrado pelas câmaras municipais, que se estenderia até o século XIX, para a reconstrução de Lisboa. Em vão, ao longo de todo o século XVIII, as câmaras de diversas vilas questionaram a manutenção do imposto denominado "Subsídio voluntário", fundamentadas nas queixas dos povos sobre as pesadas taxas que já pagavam em Minas Gerais. ${ }^{51}$

Outrossim, as chamadas Bulas da Santa Cruzada incomodaram a ponto de suscitar protestos anônimos, que circularam nas freguesias do bispado de Mariana. Conforme o discurso pastoral, a contribuição existia para financiar as causas da Igreja. A Bula da Santa Cruzada se destinava à defesa dos domínios católicos na África, apesar de haverem sido desviados por ocasião da dominação de Castela. Os fiéis deveriam tomar bulas - ou seja, adquirir bilhetes, e depositar contribuições, em ocasiões determinadas pela hierarquia episcopal em troca de indulgências. A exortação a tal prática dava-se às missas e também por meio das visitas pastorais. No ano de 1756 o Doutor Teodoro Ferreira Jácome questionava em visita a ausência da caixa com furo para arrecadar as contribuições para a Bula da Santa Cruzada. Reclamava que pela falta da caixa na matriz e capelas da freguesia, os cofres das bulas

construção de igreja é usado em sua defesa em processo pelo qual responde, no tribunal eclesiástico, por depredação de patrimônio, fl. 29-29v; 4519 - sobre a utilização das esmolas pela Venerável Ordem Terceira do Carmo de Mariana, fl. 39v-40. Sobre o uso das esmolas e o sumiço dos livros de contas da Irmandade das Almas, processo 2922 - 01-03-1782. Sobre a concessão de esmolas como socorro em hora de necessidade, vide o mesmo fundo, processos 2894B - 09-02-1767 e processo 2791 - 26-01-1773. Sobre furto das esmolas da Irmandade do Rosário: Epistolário dos Bispos, n. 1600. Processo n. 2942 - 1765.

${ }^{51}$ FAORO, Raimundo. Os donos do poder: formação do patronato político brasileiro. São Paulo: Globo, 2004. 
experimentavam "grandes prejuízos e os penitentes gravíssimos danos em suas consciências." Para remediar estes danos, mandava ao pároco que fizesse ciente ao Reverendo Doutor Félix Simões de Paiva, Comissário da Bula, no tempo de três meses, para que mandasse ordem ao Tesoureiro, ou o Mamposteiro da Bula, e pusesse na Igreja "uma caixa com o letreiro por cima que diga 'Caixa da Bula da Cruzada' fechada com duas chaves das quais uma terá o reverendo pároco e outra terá o dito tesoureiro, com um buraco por cima por onde se lancem as ditas esmolas". A caixa de esmolas deveria ficar em lugar público e o Reverendo Pároco informaria aos capelães e os confessores, para ficarem cientes de sua existência. Estes mandassem seus penitentes lançar as ditas esmolas nos casos que acharem nos confessionários as ditas aplicações". ${ }^{52}$

As disputadas esmolas se revelavam incómodas. Uma carta pastoral de Dom Frei Manuel da Cruz denunciava a distribuição de panfletos anónimos contra à Bula da Santa Cruzada, incidente pelo qual responsabilizava os párocos do bispado. Alguns párocos não faziam a publicação da Bula na terceira Dominga do Advento de cada um ano como lhes foi ordenado e 1759. Outros faltam em mandar certidões de quantas mil pessoas há nas suas freguesias e destas pouco mais ou menos quantas poderão tomar Bula de meia oitava, quantas de meia pataca, quantas de quatro vinténs, e nisso acreditava que os movia uma grande displicência. Outros párocos não querem assistir junto a alguns tesoureiros da Bula a abertura da caixinha, que deve haver em cada uma das matrizes e capelas. Estas deveriam ser abertas na presença de ambos e passar o pároco a certidão ex-oficio do rendimento. ${ }^{53}$

O bispo exortava a todos que abominassem e detestassem semelhantes doutrinas e orientava que os pregadores e confessores assim os persuadissem e aconselhassem nos púlpitos e confessionários para benefício espiritual dos nossos diocesanos, movendo-os a que tomem Bula não só para si, mas também para seus filhos e escravos, pois é grande lástima que estes

${ }^{52}$ Visita do Doutor Teodoro Ferreira Jácome à freguesia de Nossa Senhora da Boa Viagem de Curral Del Rei, em 29/10/1756. AEAM, Livro de Disposições Pastorais número 3, prateleira W, fl. 23.

${ }^{53}$ Pastoral de Sua Excelência Reverendíssima Sobre a Bula da Santa Cruzada, de 10/03/1762. AEAM, Secção de Livros Paroquiais, Prateleira H, Livro 14 de Visitas e Fábrica, fl. 112v-113v. 
deixem de lucrar tão inexplicáveis e preclaras indulgências e outras graças por não despenderem seus senhores uma tenuíssima esmola em lhes tomar Bula. ${ }^{54}$

Para dom frei Manuel da Cruz, alguns Párocos, Capelães e outras Pessoas Eclesiásticas, erradamente instruídas, aconselham que na suposição de se pagar o quinto da Bula, por ser diminuído o valor do ouro por arbítrio e mandado régio, os podem tomar de menor preço de que aquela porque estão obrigados a tomar, sem advertirem que a Bula de dois vinténs só vale aos filhos de famílias, aos escravos e aos pobres mendicantes. Os mais, orientava, a devem tomar de esmola de quatro vinténs de meia pataca e de meia oitava, conforme os seus juros e rendimentos. Os cabeças de casal, marido, mulher, devem tomar ambos do mesmo preço por serem ordens comuns. ${ }^{55}$

Algumas pessoas, apontava o bispo, mandavam vir Bulas do Rio de Janeiro pela esmola em que lá estão taxadas. Condenando a manobra, que assim "Ihes não vai causar alguma das graças na mesma Bula concedidas". Mostrava-se, ainda, bastante incomodado pois soubera que "na Vila de São João Del Rei houve quem esquecido do carácter de fiel católico espalhou papeis contra a Bula dizendo que não era necessária porque também não a havia em Alemanha e no Reino de França". Acusava a falsidade do panfleto, que causava "murmuração" entre os fiéis: "de cuja repreensível doutrina se incitou talvez o abominável sussurro e rumor que se tem espalhado de que se não deviam tomar Bulas porque impedido o recurso à Cúria Romana estar acabado o Breve da Concessão.” Explicava o bispo que não houvera a publicação na corte de Lisboa, porque no primeiro domingo de Julho de 1761 fora o dia o Beija-Mão a Sua Majestade Fidelíssima e Altezas pelos anos do Sereníssimo Senhor Infante Dom Pedro. Assim constava da Pastoral que expediu o Ilustríssimo Comissário da Santa Cruzada. ${ }^{56}$

${ }^{54}$ Pastoral de Sua Excelência Reverendíssima Sobre a Bula da Santa Cruzada, de 10/03/1762. AEAM, Secção de Livros Paroquiais, Prateleira H, Livro 14 de Visitas e Fábrica, fl. 112v-113v.

${ }^{55}$ Pastoral de Sua Excelência Reverendíssima Sobre a Bula da Santa Cruzada, de 10/03/1762. AEAM, Secção de Livros Paroquiais, Prateleira H, Livro 14 de Visitas e Fábrica, fl. 112v-113v.

${ }^{56}$ Pastoral de Sua Excelência Reverendíssima Sobre a Bula da Santa Cruzada, de 10/03/1762. AEAM, Secção de Livros Paroquiais, Prateleira H, Livro 14 de Visitas e Fábrica, fl. 112v-113v. 
Muito provavelmente tal carta pastoral foi expedida em atenção ao prometido ao Comissário Geral da Bula da Santa Cruzada, Paulo de Carvalho e Mendonça em 1761; pois o bispo havia respondido a uma carta deste dignitário, garantindo diligências para apurar o culpado "pelos escandalosos erros contra a Bula da Santa Cruzada", e que se fosse eclesiástico, "lhe darei a conhecer os seus abomináveis erros, pela justiça". ${ }^{57}$

Na Europa, estudos apontam descontentamentos dos fiéis e até um certo descrédito em relação aos sacramentos, que remontavam a longa data. Há processos no Santo Ofício sobre as fartas críticas dos cristãos-velhos pelas vendas de bulas. Havia também denúncias de pessoas que declaravam não acreditar em seus benefícios. Duvidava-se das indulgências concedidas, das contas bentas, da absolvição dos pecados e da salvação das almas. ${ }^{58}$

Nas Minas Setecentistas, este descrédito não deixava de atingir a hierarquia eclesiástica e o clero. Especialmente em fins do século XVIII, quando a população já estava sobrecarregada devido à pesada carga de tributos metropolitanos e o esgotamento das jazidas auríferas, com claros sinais de decadência das zonas mineradoras. Os moradores de freguesias encomendadas arcavam, ainda, com as custas dos serviços eclesiásticos, festas, construções, reformas de templos e hospitais. Estudos apontam que a situação nas Minas favorecia que a miséria abrisse um profundo abismo social entre os privilegiados e a multidão de pedintes, vadios, aventureiros e desgraçados que, a não morrer de fome ou doenças, viviam de esmolas. ${ }^{59}$ Por outro lado, conforme indicam estudos, o controle das instituições de

${ }^{57}$ Copiador de algumas cartas particulares do Excelentíssimo e Reverendíssimo. Dom Frei Manuel da Cruz (1739-1762). Transcrição, Organização e notas de Aldo Luiz Leoni. Ouro Preto: Universidade Federal de Ouro Preto, 2003. Brasília: Editora do Senado, 2009. Copiador de algumas cartas particulares de Dom Frei Manuel da Cruz. Organização de Mons. Flávio Carneiro Rodrigues e Maria José Ferro. Mariana: Dom Viçoso, 2008., fls. $112 \mathrm{v} ; 114-115 \mathrm{v} ; 173 \mathrm{v} ; 209 \mathrm{v}-210$.

${ }^{58}$ De acordo com Carlo Ginzburg, muitas contestações e críticas panfletárias sugeriam descrédito em relação aos sacerdotes e benefícios eclesiásticos na Europa à época das Reformas.GINZBURG, Carlo. O queijo e os vermes: o cotidiano e as idéias de um moleiro perseguido pela Inquisição. Trad. M. B. Amoroso. Trad. dos poemas José P. Paes. São Paulo: Companhia das Letras, 2006, p. 39.

${ }_{59}$ SOUZA, L. M. O Diabo e a Terra de Santa Cruz: Feitiçaria e Religiosidade Popular no Brasil Colonial. 9ª reimpressão. São Paulo: Companhia das Letras, 2005, p. 100. 
assistência e os mecanismos de arrecadação de esmolas, era um negócio bastante rentável para a Igreja e para a coroa. ${ }^{60}$

Assim, não obstante aquele universo de pobreza e temor, predominante na capitania, as acções coordenadas da hierarquia eclesiástica e da coroa visavam persuadir os sectores da população que podiam contribuir. Talvez guardassem algum lastro da reacção metropolitana contra o extravio das contribuições públicas, na defesa das preocupações com a arrecadação na região. Certamente as autoridades não assistiriam inertes à ampliação de mais um canal de fuga de recursos: as esmolas. O panorama local não era dos mais tranquilos, uma vez que boa parte das correspondências das autoridades da Fazenda e do Governo da Capitania a Lisboa tratavam de medidas contra os descaminhos e de pesquisas para o aumento da produção aurífera. Tudo isso evidencia as dificuldades para se fazer funcionar a engrenagem da administração, fisco e defesa, e ainda controlar as brechas de extravios de riquezas. O fisco era aspecto fundamental para o funcionamento da máquina administrativa, especialmente se situarmos os fatos no conturbado contexto internacional, como os conflitos entre as potências europeias, na Guerra dos Sete Anos. ${ }^{61}$

A carta pastoral que acusava os erros e murmurações contra a bula da Santa Cruzada foi uma das últimas da vida de Dom Frei Manuel da Cruz. Naquele mesmo ano, em razão de grave enfermidade do bispo, o doutor Teodoro Ferreira Jácome passou a governar o bispado e administrar o seminário. $\mathrm{O}$ solene testamento era tipicamente barroco e coerente com a doutrina apregoada nos sermões ascéticos e nas dezenas de cartas pastorais por meio das quais se dirigira aos diocesanos: a caridade com os vivos e com os falecidos, as esmolas e o culto a São Bernardo de Claraval, aos Três Sagrados Corações, bem como as orações e missas. Muitas missas de corpo presente. Apenas no território do bispado, seriam 300, na Sé e igrejas da cidade; 200 no altar privilegiado do Sagrado Coração de Jesus,

${ }^{60}$ SILVA, Renata Rezende. Entre a ambição e a salvação das almas: a atuação das ordens regulares em Minas Gerais (1696-1759). São Paulo, 2005. Faculdade de Filosofia, Letras e Ciências Humanas da Universidade de São Paulo, dissertação de Mestrado, p. 139.

${ }^{61}$ WEHLING, Arno \& WEHLING, Maria José C. Formação do Brasil colonial. Rio de Janeiro: Nova Fronteira, 1994, p. 211. 
Maria e José da catedral; 100 na capela do seminário, pelos padres que ali residissem; 100 no Recolhimento das Macaúbas. No Rio de Janeiro, encomendava-se 200 missas na capela dos Barbadinhos e 200 na igreja de Santa Eulália. Em Portugal, deviam ser celebradas 200 missas na igreja de Santo André de Cristellos, no bispado do Porto, e 1600 missas na igreja dos capuchinhos de Arrifana de Sousa. ${ }^{62}$

\section{Conclusões}

Neste estudo analisamos, a partir de textos oficiais e anónimos do século XVIII, as acções coordenadas da hierarquia eclesiástica e da coroa, no sentido de reprimir a acção dos esmoleiros. Este trabalho coercitivo se realizou ao mesmo tempo em que as instituições coloniais apregoavam um discurso em prol da solidariedade pelas vias institucionais, visando a delimitar as práticas de caridade aos círculos das paróquias e capelas do bispado. Estas aproximações nos ajudam a destacar algumas conexões entre os mecanismos do Estado e do episcopado, para consolidar sua presença nos territórios de conquista cuja manutenção exigia constante articulação e estratégia. Ainda que não o fizessem sem conflitos e dissensões, a orientação do padroado régio ultramarino era a de incentivar a união de forças centrípetas convergindo para a consolidação do mando metropolitano na capitania de Minas Gerais.

Ao mesmo tempo, deve-se ressaltar que as práticas da população, bem como os relatos de abusos e furtos revelam algumas reações que estão bem longe da passiva recepção da mensagem oficial. Ao contrário, as murmurações e transgressões sugerem um comportamento tenaz, da parte dos leigos, que não hesitavam em lançar mão das frestas do sistema e transgredir a norma, a procurar livrar-se dos seus liames, bem como da forte carga tributária praticada na capitania do ouro no século XVIII.

${ }^{62}$ TRINDADE, R. O. Arquidiocese de Mariana. $1^{\text {a }}$ Ed., Op. Cit., pp. 178-180. 